\title{
Przyczynek do historii powstania rejestrów gruntowych
}

\section{Pierwsze wzmianki o sposobach oznaczania granic własności i re-} jestrowania praw do nieruchomości gruntowych. Najwcześniejsze ze znanych form rejestracji podmiotowych praw do posiadania gruntami odkryte zostały w dolinie Eufratu i Tygrysu i datowane są na około 6500 lat p.n.e. Na terenach istniejącego w czasach babilońskich miasta Nuzi, odnalezionych zostało 200 tablic $\mathrm{z}$ wypalanej gliny, na których odczytano dane dotyczące opisu, wymiarów i ceny zakupu działek gruntowych, które stanowić miały dowód nabycia praw do posiadania rzeczy i korzystania z jej pożytków ${ }^{1}$. Prawo do ziemi chronione było $\mathrm{w}$ tamtym regionie $\mathrm{w}$ ten sposób, że punkty graniczne wyznaczające zasięg (granice) tegoż prawa stabilizowane były odpowiednio przygotowanymi kamieniami (stelami) granicznymi, czego dowodem jest odnaleziony w miejscowości Telloh, zamieszkałej przez ludy semickie (dolina Eufratu), kamień graniczny oraz gliniane tablice (datowane na ok. 4000 lat p.n.e.). Pismem klinowym zostały na nich wyryte informacje dotyczace opisu tych gruntów: w tym ich powierzchnie, wymiary, a także dane identyfikujące ich posiadacza oraz zaklęcia mające chronić zarówno granice posiadania, jak i ich właściciela².

Obowiazek zapisywania aktów przeniesienia własności na glinianych tabliczkach i ich przechowywania ustalony został wprost w Kodeksie Hammurabiego $^{3}$. Publiczne złamanie tabliczki $z$ umową kupna-sprzedaży równoznaczne było z unieważnieniem całej transakcji ( $\$ 37$ Kodeksu). Wyodrębnione nieruchomości, stanowiące własność indywidualna, były oznaczane na gruncie kamiennymi głazami wysokości do $1 \mathrm{~m}$, zwanymi kadurru, które stanowić

${ }^{1}$ J. Wolski, Kataster podatku gruntowego na ziemiach polskich, „Przegląd Geograficzny” 2001, nr 73, poz. 1-2, s. 107-108.

Ibidem.

${ }^{3}$ Kodeks Hammurabiego to jeden z najstarszych kodeksów świata. Został sporządzony przez króla Hammurabiego (1728-1686 p.n.e.), szóstego przedstawiciela dynastii babilońskiej. Odnalazła go w Suzie naukowa ekspedycja francuska. Tekst kodeksu wyryty został na bloku diorytu wysokości przeszło $2 \mathrm{~m}$, pismem klinowym - por. K. Krasowski, B. Lesiński, K. Sikorska-Dzięgielewska, J. Walachowicz, Powszechna historia państwa i prawa, Poznań 1993, s. 274. 
miały dowód nadania ziemskiego przez władcę. Na kamieniach tych wykute były napisy zawierające informacje o akcie nadania i przejściu własności na rzecz określonej osoby, a także różnego rodzaju zaklęcia, które chronić miały ich posiadacza przed ingerencją osób trzecich ${ }^{4}$. Każdy kamień graniczny kadurru miał swoją kopię, która przechowywana była w świątyni jako niezależny dowód potwierdzający nabyte prawa na wypadek ich kwestionowania. Kamienie kadurru pełniły zarówno funkcję dokumentu potwierdzającego na gruncie zasięg posiadanych praw, jak i dokumentu, który złożony w świątyni (rejestrze publicznym) stanowić miał gwarancję ochrony własności, stając się przy tym symbolem pochodnego nabycia prawa własności indywidualnej ${ }^{5}$.

Zgodnie z prawem asyryjskim, przeniesienie na nabywcę prawa do gruntu wymagało zachowania formy publicznego sporządzenia aktu sprzedaży (duppa dannatu) przed władzą królewską. W niektórych regionach starożytnej Asyrii (np. Kirkuk-Nuzi) do skutecznego przeniesienia prawa własności względnej pomiędzy stronami umowy niezbędne było dokonanie pomiarów sprzedawanej działki gruntu za pomocą urzędowej miary, wykonane przez osobę „,cieszącą się powszechnym szacunkiem”, zwanej mušelmŭ. Spełniała ona funkcję publicznego zidentyfikowania przedmiotu kontraktu, który stanowił podstawę sporządzenia kolejnego dokumentu rejestrującego zawarta umowę, podlegał publicznemu ogłoszeniu, dzięki czemu zawarta umowa wywierała skutek wobec osób trzecich ${ }^{6}$. Sporządzone dokumenty sprzedaży i ich kopie przechowywane były w sądach (rejestrowych) lub świątyniach pełniących taką funkcję. Uchybienia, zarówno w zakresie formy, jak i trybu zbycia i zarejestrowania kontraktu sprzedaży, stanowić mogły przyczynek do złożenia oskarżenia o kradzież rzeczy, co mogło się skończyć karą śmierci

W starożytnych Atenach granice własności ${ }^{8}$ oznaczane były kamiennymi głazami zwanymi horoi (horos) ${ }^{9}$, na których umieszczano nie tylko informacje pozwalające zidentyfikować posiadacza nieruchomości, ale także wzmianki o udzielonych pożyczkach, które zabezpieczone zostały na nieruchomości (słupy zastawne). Inskrypcje umieszczone na kamieniach granicznych świadczyć miały między innymi o tym, że tak oznaczona działka gruntu obciążona była prawem odkupu w przypadku jej sprzedaży. Kamienne słupy, z grecka zwane Ǒpos, Ǒpor służyć miały zapewnieniu bezpieczeństwa w obrocie prawnym, informując każdego zainteresowanego, że tak oznaczona nieruchomość stanowi zabezpieczenie majątkowe wierzytelności wynikające $\mathrm{z}$ określonego

${ }_{5}^{4} \mathrm{R}$. Taubenschlag, Rzymskie prawo prywatne na tle praw antycznych, Warszawa 1955, s. 114.

${ }^{5}$ K. Koranyi, Powszechna historia państwa i prawa, t. I, Warszawa 1961, s. 16; por. T. Stawecki, Rejestry nieruchomości, księgi hipoteczne i księgi wieczyste od czasów najdawniejszych do XXI wieku, „Studia Iuridica” XL (2002), s. 168-169.

${ }^{6}$ R. Taubenschlag, Rzymskie prawo prywatne, s. 116

Ibidem.

${ }^{8}$ Prawo greckie nie rozróżniało definitywnie podziału prawa własności i posiadania (katechejn).

T. Stawecki, Rejestry publiczne. Funkcje instytucji, Warszawa 2005, s. 183. 
stosunku zobowiązaniowego, czego potwierdzeniem może być cytat Polluksa IX 29: „Jest zaś horos rejestrem publicznym umieszczonym na majątkach i gruntach, postawionych dla tych, którzy biorą je w zastaw, ze względu na to, co dłużni są właściciele; na horosie jest dla nich zapisane, oto że grunt ten albo domostwo jest zajęty z powodu długu, aby nikt nie zawierał umowy $\mathrm{z}$ tymi, których grunty zostały zajęte"10. Na słupach zastawnych umieszczano szczegółowe inskrypcje informujące o tym czy zastaw dotyczy gruntu, czy też całego majątku dhużnika, ujawniano imię wierzyciela, podawano informacje dotyczące imienia archonata (najważniejszego urzędnika polis) za czasów którego dokonano zabezpieczenia długu, czasem podawano także sumę zabezpieczonych zobowiązań pieniężnych ustanowionych w formie hypotheca ${ }^{11}$.

Przyjęto zasadę, że w przypadku gdy wysokość zaciągniętego zobowiązania (zastawu) przekraczała wartość obciążonej działki gruntu, wierzycielowi przysługiwało prawo do zatrzymania jego właściciela jako najemnika lub uprawnienie do jej sprzedaży w celu odzyskania brakującej kwoty ${ }^{12}$, co doprowadziło do masowego ,wykupu” tak zastawionych nieruchomości przez posiadaczy ziemskich.

Słupy zastawne usunął dopiero Solon, wprowadzając w latach 594-593 p.n.e. reformy, w ramach których anulował on zobowiązania ustanowione wobec polis, co nazwane zostało strząśnięciem ciężarów (sesjachteja), wykupując na koszt państwa byłych właścicieli zajętych gruntów zastawnych, znosząc tym samym instytucję ,niewoli za długi". Byłym właścicielom zwrócone zostały odebrane im wcześniej nieruchomości, a także ustanowione zostały ograniczenia obszarowe, ustalające maksymalną wielkość majątku ziemskiego, jaki może być w posiadaniu jednej osoby.

Według przekazu Platona informacje o działkach gruntowych, jakie przydzielane były osadnikom, spisywane były na tabliczkach z cyprysowego drewna, które przechowywano w świątyni ,na późniejszy użytek"13.

Zbycie prawa do nieruchomości wiązało się z koniecznością ogłoszenia swojego zamiaru na sześćdziesiąt dni, licząc od daty zamierzonej transakcji, przed urzędnikiem, co służyć miało ochronie praw nabywcy czy też potencjalnych wierzycieli ${ }^{14}$. Wymóg formalny w zakresie ogłoszenia wiadomości o zbyciu nieruchomości realizowany był w niektórych państwach-miastach greckich poprzez wywieszenie w miejscu publicznym wiadomości o planowanej transakcji lub w formie ogłoszenia podawanego do wiadomości przez

${ }^{10} \mathrm{~J}$. Rominkiewicz, Opieka nad męskimi pupilami w prawie ateriskim, Wrocław 2003, s. 117.

${ }^{11}$ Na słupach horoi nie były podawane sumy dłużne, które ustanowione zostały w formie apotimema - ta forma zabezpieczenia długu (inne niż hypotheca) stosowana była przy dzierżawie majątku i zabezpieczeniu posagu - por. ibidem, s. $117 \mathrm{i} \mathrm{n}$.

12 T. Maciejewski, Historia powszechna ustroju i prawa, Warszawa 2007, s. 12.

13 Platon, Prawa, Warszawa 1960, s. 200.

14 T. Stawecki, Rejestry nieruchomości, s. 169. 
herolda na kilka dni przed planowaną sprzedażą oraz wpisaniem do prowadzonych urzędowych rejestrów ${ }^{15}$.

Nie we wszystkich jednak greckich miastach-państwach, prawa do gruntów były w ten sposób rejestrowane i tym samym chronione. W niektórych $\mathrm{z}$ nich, na przykład w Sparcie, obowiązywała bowiem zasada, zgodnie z którą każdemu obywatelowi przysługiwało prawo do jednej i jednakowej wielkości działki gruntu, przydzielonej mu w wyniku losowania. Sprawia to, że faktyczny obrót dokonywał się tak naprawdę na podstawie prawa spadkowego i rodzinnego ${ }^{16}$. Tak nadane działki gruntowe nie mogły stanowić przy tym przedmiotu zabezpieczenia wierzytelności czy też przeniesienia praw na inną osobę (alienowane).

W Egipcie w I w.n.e. funkcjonował już pierwszy, we współczesnym tego słowa rozumieniu, rejestr nieruchomości nazwany archiwum akt posiadania (bibliotheke enktesenon), którego podstawowym zadaniem było gromadzenie dowodów potwierdzających posiadanie praw do nieruchomości i rzeczowego zabezpieczenia udzielonych wierzytelności (obciazżenia jej hipoteka). W prowadzonych rejestrach zapisywane były także inne ważne informacje o samej nieruchomości i jej właścicielu, jak również pośrednio z nią związane, a dotyczące na przykład liczby niewolników wykonujących określone prace związane $\mathrm{z}$ opisywaną rzecza, a wszystko to po to, aby ,żadna osoba nabywająca prawa nie mogła zostać oszukana w wyniku swojej niewiedzy"17.

Wprowadzony system ksiag rejestrowych służyć miał zapewnieniu pewności i bezpieczeństwa obrotu prawnego, a także wykorzystywany był do celów fiskalnych, umożliwiając władcy jednoznaczne ustalenie osoby zobowiązanej do uiszczenia należnych podatków i ich wielkości. Warto także odnotować, że czynności te wykonywane były za pośrednictwem sieci specjalnych biur zlokalizowanych w stolicach okręgów, które zobowiązane były do prowadzenia ksiąg zwanych diastromata, w których zapisywano wszelkie dane podlegające z urzędu ujawnieniu. Według obowiązującego wówczas systemu rejestrowania praw do ziemi, wymagany był wpis do księgi (diastromata). Dokonywano go w ramach określonej procedury ${ }^{18}$ zwanej katagraphe, w trakcie której sporządzany był akt przeniesienia praw do ziemi (dziś zwany aktem notarialnym), a następnie - na wniosek urzędnika (notariusza), który go spisał - przekazywany był do biura prowadzącego księgi, a to z kolei wydawało zarządzenie (epistalma) potwierdzające ważność dokonanej transakcji. Wydane zarządzenie stanowiło dopiero podstawę ujawnienia nabytych praw w księdze (wpis konstytutywny).

\footnotetext{
${ }^{15}$ K. Koranyi, Powszechna historia, s. 83.

${ }^{16}$ Ibidem, s. 206.

17 T. Stawecki, Rejestry nieruchomości, s. 171.

${ }^{18}$ Dziś zwanej instytucją wpisu do rejestru.
} 
W epoce hellenistycznej w czasie obowiązywania prawa aleksandryjskiego, dla skuteczności przeprowadzenia czynności alienacji, zbywca zobowiązany był do dokonania aktu formalnego, polegającego na publicznym wydaniu zbywanej rzeczy nabywcy, w trakcie której zaproszeni przez niego sasiedzi składali oświadczenie, że jest on uprawnionym do sprzedaży nieruchomości będącej przedmiotem kontraktu. Za uczestnictwo w tych czynnościach sąsiedzi świadkowie otrzymywali stosowne wynagrodzenie w postaci opłaty granicznej. Strony kontraktu zobowiązane były do opłacenia należnego podatku i złożenia skarbnikowi miasta sprawozdania z dokonanych czynności, który następnie sporządzał na tej podstawie dokument publiczny, będący podstawą wpisu do katastru nieruchomości. Dopiero z chwilą ujawnienia aktu sprzedaży w prowadzonych rejestrach uznawano, że własność do rzeczy bezwzględnie przysługiwała jej nabywcy ${ }^{19}$.

O roli i znaczeniu prowadzonych w tamtym czasie rejestrów, ale także egipskich mierniczych, może świadczyć zapis Herodota: „Jeżeli okazało się, iż poddanemu woda zabrała część pola, wówczas król wysyłał swoich urzędników, aby skonfrontowali wielkość pola i odpowiednio zmniejszyli podatek"20. Przywołane zapisy mogą stanowić dowód świadczący o tym, jaką wage przywiązywano wówczas do aktualności danych dotyczących ewidencji gruntów i jakie pełniły one ważne funkcje publicznoprawne.

Rejestrowanie przeniesienia praw, gromadzenie dowodów dokonanych czynności, jak i stabilizacja granic nieruchomości, miały służyć zagwarantowaniu pewności i bezpieczeństwa obrotu prawnego, ale także możliwości jednoznacznego ustalenia osób zobowiązanych do świadczenia danin publicznych na rzecz władcy (do celów podatkowych).

Jak ważny był to w przeszłości problem, świadczyć może fragment instrukcji wydanej około 1400 lat p.n.e. przez Departament Pomiarów w ówczesnym państwie faraonów, w którym zapisano: „Nie usuwać kamieni granicznych na polach i nie zmieniać pozycji taśm mierniczych" (Amenhotope, syn Kanakhta, Nauczania, rozdział VI) ${ }^{21}$. W przywołanej instrukcji opisano zarówno tryb, jak i procedury załatwiania sporów granicznych opartych na sporządzanej wówczas dokumentacji, czego potwierdzeniem może być zawarty w niej zapis: „Kiedy petent przychodzi i oznajmia: Nasze znaki graniczne zostały usunięte - musi uzyskać wgląd do informacji zapisywanych i zapieczętowanych przez odpowiedniego urzędnika i w konsekwencji odzyskać to, co zostało mu odebrane przez zgromadzenie, które usunęło znaki graniczne"22.

${ }^{19}$ R. Taubenschlang, Rzymskie prawo prywatne, s. 117.

${ }^{20}$ Herodot, Dzieje, Warszawa 1954, s. 164.

${ }^{21}$ J.F. Brock, Who Were the First Surveyors, Four Surveyors of the Gods: In the XVIII Dynasty of Egypt-New Kingdom c. 1400 B.C, „International Federation of Surveyors. Article of the Month", March 2005.

22 Ibidem. 
Rozwój miernictwa w starożytnym Egipcie wynikał z konieczności zapewnienia możliwości jednoznacznego odtworzenia położenia znaków granicznych, wyznaczających zasięg wyodrębnionych działek gruntów, podlegających opodatkowaniu, niszczonych corocznymi wylewami Nilu w taki sposób, aby zagwarantować każdemu posiadaczowi poczucie pewności, co do możliwości prawidłowego oznaczenia przedmiotu jego praw do ziemi. Kiedy woda opadała, niszcząc przy tym znaki graniczne (miedze, kamienie itp.), dochodziło często do powstawania sporów, które rozstrzygane były przez inspektorów uprawnionych do odtwarzania granic na gruncie, umieszczania kamieni granicznych $i$ ich pomiaru.

Sceny przedstawiające pracę inspektorów z udziałem tzw. napinaczy sznurów odnaleźć można między innymi na ścianach grobowców, w których pochowani zostali staroegipscy miernicy (ok. 1400 p.n.e). Miernicy staroegipscy, zwani także napinaczami sznurów, byli wysokimi funkcjonariuszami urzędu katastralnego, którym przysługiwało prawo noszenia białej lnianej peruki jako oznaki ich godności. Byli dobrze opłacanymi urzędnikami faraona, czego dowodem mogą być okazałe grobowce, na ścianach których przedstawione zostały sceny z ich życia, w tym stosowane wówczas techniki wykonywania pomiarów ${ }^{23}$.

W Rzymie, podobnie jak i w innych rejonach świata, nieruchomość gruntowa oznaczana była przez ustawianie głazów granicznych, a samą treść aktu przeniesienia własności spisywano publicznie, na drewnianych tabliczkach (tabula cerata) ${ }^{24}$, przed przedstawicielem władzy publicznej (pretorem lub gubernatorem) w trybie procesowym, w wyniku którego dochodziło do odstapienia prawa lub w wyniku czynności prywatnych, ale wymagających obecności świadków, a także osoby odpowiedzialnej za rzetelne ustalenie zapłaty zwanej librepens (,trzymającej wagę") ${ }^{25}$. Określone czynności formalne i ceremonialne związane z przeniesieniem praw do nieruchomości służyć miały utrwaleniu w świadomości osób przy tym obecnych wagi dokonanych czynności i gwarantować jednocześnie ich wieczyste trwanie ${ }^{26}$.

${ }^{23}$ K. Sawicki, Pięć wieków geodezji polskiej, Warszawa 1964, s. 8-9; I. Salmon, Geodezja w starożytnym Egipcie, dostęp: www. gmat.unsw.edu.au/currentstudents/ug/projecst/salomon/salomon.htm.

24 Ibidem, s. 172

25 K. Kolańczyk, Prawo rzymskie, Warszawa 1997, s. 299-300.

${ }^{26}$ Gaius Institutiones - księga I, cz.18. 119-122. „Jest bowiem mancipatio, jak i to wyżej powiedzieliśmy, jakaśs udawaną sprzedażą jest to też prawo właściwie obywatelom rzymskim; a rzeczy tej tak się dokonuje: w obecności nie mniej niż pięciu dojrzałych obywateli rzymskich, a poza tym jeszcze jednego tego samego stanu, który trzyma spiżową wagę i zwany jest libripensem, ten który otrzymuje rzecz w mancipium trzymając rzecz, tak rzecze: Ego hominem ex iure quiritium meum esse aia isque mihi emptus esto hoc aere aeneaque libra; potem uderza wagę spiżem i ten spiż daje temu, od kogo przyjmuje w mancipium, jakby w miejsce ceny". Dostęp; http://www.karnykodeks.pl/prawo/gaius-institutiones-ksiega-i-cz18.html. 
Jak ważny był to problem dla ówczesnych Rzymian, świadczyć może fakt, że dla ochrony granic własności pomiędzy prywatnymi posiadłościami ustanowiono boga zwanego Terminusem, którego posag był złożony w świątyni Jowisza na Kapitolu, a święto ku jego czci - zwane Terminaliami - obchodzono 23 lutego ${ }^{27}$. W tym dniu kamienie graniczne dekorowane były kwiatami, a wokół nich składano ofiary.

Problematyka oznaczania granic własności ziemskich znalazła także swoje miejsce w ustawie XII tablic (lex tabularum) - spisanej w latach 451 -450 p.n.e - zajmującej wyjątkowe i szczególne miejsce w ustawodawstwie rzymskim $^{28}$. W ułamku 69 tablicy ósmej przywołanej ustawy zapisano, że ,aby granice własności gruntowych nie były wątpliwe, pięć stóp odległości na wzór prawa Solona, wolne miejsce między gruntami właściciele zostawić powinni; a przedawnienie temu rozporządzeniu szkodzić nie ma". Kolejny przepis (ułamek 70, tablica 8) stanowił zaś, że „,w sprawach o granice między sąsiadami, pretor wyznaczał trzech arbitrów"29, którzy spór rozsądzali.

W prawie rzymskim, granica rozdzielająca sasiadujące ze sobą tereny rolne traktowana była jako rodzaj współwłasności gruntowej, który mógł ulec rozgraniczeniu (podziałowi) wyłącznie na zgodne żądanie zainteresowanych posiadaczy ziemskich. W przypadku agri limitati wokół każdej parceli wytyczony był przez geometrów pas gruntu (limes) szerokości 5 stóp, który był wyłączony z uprawy i jako taki nie podlegał zasiedzeniu (usucapioni). Miał on służyć do celów komunikacyjnych, a także zapewniać posiadaczom przyległych posiadłości moźliwość uprawy ziemi ,przy nawracaniu pługiem"30.

Srodkiem wydzielonego limesu (miedzy) przebiegała linia graniczna (finis), dzieląc go na pasy szerokości $2 \frac{1}{2}$ stopy, które - stanowiąc integralną część przylegających posiadłości ziemskich - były obciążone jednocześnie prawem (służebnościa), umożliwiającym wspólne z nich korzystanie w określonych celach związanych z obsługa tych działek.

W przypadku naruszenia granicy działki rolnej każdy z właścicieli lub posiadaczy sąsiadujących gruntów mógł wnieść do sądu powództwo o sprostowanie granicy, zwane acito finium regundorum, które miało przy tym charakter osobisty (acito in personam) i różniło się od powództwa wydobywczego między innymi tym, że w jego toku nie rozstrzygano sporów dotyczących stosunków własnościowych (roszczenie petytoryjne) w odniesieniu do spornego pasa gruntu czy też praw do jego posiadania (roszczenie posesoryjne).

${ }^{27}$ T. Czacki, O litewskich i polskich prawach, o duchu, źródlach, zwiazku i o rzeczach zawartych w pierwszym statucie dla Litwy 1529 roku wydanym, t. 2, Warszawa 1801, s. 176.

28 K. Kolańczyk, Prawo rzymskie, s. 37-39.

29 A. Korwicki, Proces graniczny, Wilno 1827, s. IX.

${ }^{30}$ S. Wróblewski, Zarys wykładu prawa rzymskiego, Kraków 1919, s. 84. 
W rzymskim prawie klasycznym ${ }^{31}$ czynność przeniesienia prawa do rzeczy z jednego podmiotu na drugi, zwana przewłaszczeniem (alienatio) lub następstwem prawnym (sukccessio), zaliczana do tzw. pochodnego nabycia własności, regulowana była dwoma fundamentalnymi zasadami prawnymi. Pierwsza z nich stanowiła, że „nikt nie może przenieść na drugiego więcej praw niż przysługuje jemu samemu (nemo plus iuris ad alium transferre potest quam ipse habet). Według zaś drugiej, prawo własności przenosi się przez wręczenie lub zasiedzenie, a nie przez naga umowę (traditipnibus et usucapionibus dominia rerum, non nudis pactis transferuntur) ${ }^{32}$. Pierwsza $\mathrm{z}$ tych zasad wyznaczała granice skutecznego nabycia prawa własności jedynie od uprawnionego zbywcy (właściciela) w zakresie przysługujacych mu praw (nabycie translatywne lub konstytutywne) ${ }^{33}$, stanowiąc, że nabycie prawa (nawet w dobrej wierze) od nieuprawnionego było absolutnie wykluczone i mogło skutkować wytoczeniem skargi windykacyjnej i koniecznością zwrotu tak zakupionej nieruchomości. Czynność nabycia prawa własności do rzeczy od nieuprawnionego mogła być sanowana jedynie poprzez instytucję zasiedzenia, w ramach której obowiązywały krótkie, bo jednoroczne lub dwuletnie terminy po upływie których mogło nastapić ,uzdrowienie nieudanego przewłaszczenia" ${ }^{34}$. Drugie z wymienionych kryteriów stanowiło natomiast, że dla skuteczności przewłaszczenia niezbędne było, oprócz spisania samego kontraktu, wywierającego skutki zobowiązujące (iusta causa), dokonanie formalnej czynności wykonawczej polegającej na wydaniu sprzedawanej rzeczy nabywcy.

W czasach Gaiusa (II w. n.e.) jednym ze sposobów przeniesienia prawa własności była - praktykowana powszechnie - metoda zwana moncipatio (czynność przy świadkach), która w początkowej swej formule (do III w. p.n.e.), sprowadzała się do bezpośredniego aktu wymiany zbywanej rzeczy w zamian za otrzymana zapłatę w postaci kruszca (zazwyczaj miedzi), w ilości odmierzonej wagą (ważenie zapłaty) ${ }^{35}$. W tej pierwotnej postaci metoda ta przetrwała do czasów wprowadzenia do obiegu pieniądza (III w.p.n.e.), który jako jednostka płatnicza podlegająca zliczaniu, wyparła tym samym konieczność ,ważenia” zapłaty. Od tego czasu stwierdzenie przejścia prawa własności

${ }^{31}$ Przyjmuje się podział prawa na trzy okresy: okres archaiczny rozpoczynający się z początkiem istnienia Rzymu aż do wojen punickich (264-146 p.n.e.), czyli do końca republiki; okres prawa klasycznego liczony od połowy III w. p.n.e., tj. początki pryncypatu, aż do 235 p.n.e., czyli panowania dynastii Sewerów; okres poklasyczny (zwany prawem wulgarnym) mierzony od końca panowania Sewerów, aż do do śmierci Justyniana I (235-565 n.e.) w którym wyróżnia się jeszcze podokres prawa justyniańskiego (527-565 n.e.) - por. K. Kolańczyk, Prawo rzymskie, s. 13.

${ }^{32}$ W. Dajczak, T. Giaro, F. Longchamps de Bérier, Prawo rzymskie u podstaw prawa prywatnego, Warszawa 2009, s. 378.

33 Translatywne nabycie oznaczało, że nabywca mógł przenieść tyle praw, ile posiadał, zaś konstytutywne dotyczyło sytuacji, w której dochodziło jedynie do częściowego przewłaszczenia posiadanych przez zbywcę praw.

${ }^{34}$ W. Dajczak, T. Giaro, F. Longchamps de Bérier, Prawo rzymskie, s. 378

${ }^{35}$ K. Kolańczyk, Prawo rzymskie, s. 298; por. W. Dajczak, T. Giaro, F. Longchamps de Bérier, Prawo rzymskie, s. 379-380. 
nad rzeczą miało charakter symboliczny, acz formalny (wywołujący skutek prawny), i ograniczało się do publicznego przekazania pomiędzy zainteresowanymi stronami jednostki monetarnej (nummus unus) lub dowolnego kawałka kruszcu (raudusculum) w obecności co najmniej pięciu świadków, będących obywatelami rzymskimi, i osoby trzymającej wagę (libripens). Czynność przeniesienia prawa własności sprowadzała się do wypowiedzenia przez nabywcę formuły, w której określał on nabywane prawo do rzeczy i symbolicznego uderzenia monetą o wagę (substytut ważenia zapłaty), którą następnie wręczał sprzedającemu jako symbol należnej zapłaty ${ }^{36}$.

Metoda mancipatio, traktowana jako formalny akt przewłaszczenia w obecności świadków, stosowana była w szczególności przy zbywaniu tzw. prawa własności kwirytalnej (łac. dominium ex iure Quiritium, proprietas), czyli oficjalnej i chronionej formy własności rzymskiego prawa cywilnego okresu przedklasycznego i klasycznego, która przysługiwała wyłącznie obywatelom rzymskim, zwanym Kwirytami, i obejmowała rzeczy ruchome i nieruchome położone na terenie Italii. Akt przeniesienia prawa własności moncipatio, poprzedzony umową kupna-sprzedaży i zapłaty, miał zatem w dzisiejszym rozumieniu charakter abstrakcyjny, bo oderwany w swej symbolice zarówno od przyczyny prawnej, tj. treści zawartej umowy, jak i elementu fiskalnego ${ }^{37}$.

Metoda ta była stosowana powszechnie do czasu wprowadzenia tzw. własności bonitarnej, uznanej przez prawo pretorskie (possessio ad interdicta), a ukształtowanej pod wpływem praktyki, która z biegiem czasu eliminowała uciążliwe czynności formalne (prawa cywilnego) związane $\mathrm{z}$ przeniesieniem własności kwirytarnej, zastępując je prostymi rozwiązaniami wydania przez zbywcę rzeczy do rąk nabywcy (traditio), które miały przyspieszyć realizację zawieranych transakcji. W wyniku tych czynności nabywca stawał się posiadaczem rzeczy (possesion civilis), która dopiero z upływem czasu $^{38}$, w wyniku zasiedzenia (usucapio), mogła stać się jego własnością kwirytalną w rozumieniu prawa cywilnego. W okresie przejściowym, prowadzącym do zasiedzenia prawa posiadacza (nieformalnego nabywcy) rzeczy były chronione interdyktami posesoryjnymi ${ }^{39}$, poprzez ekscepcje, a także specjalne powództwo petytoryjne (actio publiciana $)^{40}$, które przysługiwało posiadaczowi rzeczy w dobrej wierze.

\footnotetext{
${ }^{36}$ K. Kolańczyk, Prawo rzymskie, s. 299.

${ }^{37}$ Ibidem, s. 286-287.

${ }^{38}$ Zazwyczaj był to okres do dwóch lat.
}

39 Interdykty posesoryjne chroniły prawo posiadania, które uznane było przez prawo pretorskie. Była to pozaprocesowa forma ochrony posiadania, która - sformułowana przez pretora - ustalała zasady rozstrzygające uprawnienia stron do posiadania spornej rzeczy. Istnialy trzy typy interdyktów posesoryjnych: retinendae possessionis (utrzymanie istniejącego posiadania), recuperandae possessionis (odzyskanie utraconego posiadania) oraz adipiscendae possesionis (do nabycia nowego posiadania) - por. K. Kolańczyk, Prawo rzymskie, s. 287-288.

${ }^{40}$ Actio publiciana - powództwo, które przysługiwało posiadaczowi rzeczy w dobrej wierze, w okresie prowadzącym do zasiedzenia, o jej wydanie lub zaniechanie naruszeń, które zakładało przyjęcie pewnej fikcji prawnej, polegającej na zrównaniu praw posiadacza i właściciela w zakresie ochrony rzeczy (ochrona petytoryjna). 
W okresie poklasycznym przeniesienie prawa własności do rzeczy odbywało się w ramach czynności zwanej in iure cessio (od łac. cedere - ustapić, odchodzić), zdefiniowanej w prawie rzymskim jako metoda odstapienia prawa przed sądem i pochodnego nabycia własności kwirytalnej. Czynności te miały charakter pozornego procesu windykacyjnego, prowadzonego pomiędzy stronami umowy, w ramach którego w pierwszej jego fazie nabywca prawa, sytuowany jako powód pozorny, oświadczał przed pretorem ${ }^{41}$, dokonując jednocześnie symbolicznego dotknięcia nabywanego przedmiotu laską, że wskazana w ten sposób rzecz należy do niego ${ }^{42}$. W dalszej kolejności zbywca rzeczy (pozwany pozorny) uznawał zgłoszone powództwo lub milczał, co oznaczało akceptacje roszczenia, i znaczyło tym samym, że przegrywał on proces windykacyjny (pozorny), który kończył się aktem przyznania przez pretora „spornej" rzeczy powodowi (nabywcy) ${ }^{43}$. Z uwagi na charakter samego procesu legisakcyjnego (per legis action es) ${ }^{44}$, uczestnikami tej sformalizowanej, ale jednak abstrakcyjnej czynności prawnej in iure cessio mogli być jedynie obywatele rzymscy, posiadający zdolność sądową. Tak sformułowanego roszczenia nie można było przy tym obwarować ani warunkiem (conditio), ani też terminem (dies) jego dochodzenia ${ }^{45}$. Jako metoda pochodnego prze-

${ }^{41}$ Pretor to wyższy urzędnik w antycznym Rzymie, mający tzw. władzę mniejszą (imperium minus), zajmujący się przede wszystkim sądownictwem cywilnym - por. Mala encyklopedia, red. B. Petrozolin-Skowrońska, Warszawa 1995, s. 707.

42 Gaius Institutiones (G. 4.16): „Jeśli procesowano się co do rzeczy, rzeczy ruchome i ożywione, które można było przynieść lub doprowadzić przed urzędnika, tak windykowano przed urzędnikiem: ten, który windykował, trzymał tyczkę, potem samą rzecz chwytał, na przykład niewolnika, i tak mówił: Hunc ego hominem ex iure quiritium meum esse aio secundum suam causam, sicut dixi, ecce tibi vindicatam imposui (Ja oświadczam, że ten niewolnik jest mój wedle prawa kwirytów, zgodnie ze swoją sprawa, tak jak powiedziałem, oto wobec ciebie nałożyłem [nań] laskę) i w tej chwili dotykał niewolnika tyczka. Jego przeciwnik podobnie mówił i czynił. Skoro obaj dokonali windykacji, pretor mówil: mittete ambo hominem (Puście obaj niewolnika), oni wypuszczali. Ten, który najpierw windykował, tak drugiego zapytywał: postulo anne dicas qua ex causa vidicaveris (Żądam, byś powiedział, z jakiej przyczyny windykowałeś). Ów odpowiadał ius feci sicut vindictam imposui (Wykonałem prawo, tak jak nałożyłem laskę). W końcu ten, który najpierw windykował, mówił: quando tu iniuria vindicavisti quingentis assibus sacramento te provoco (A jeśli windykowałeś $\mathrm{z}$ obrazą prawa, wzywam byś ustanowił sacramentum pięćset asów). Przeciwnik także mówił podobnie: et ego te (I ja ciebie). Tyczki zaś używali jakby w miejsce włóczni, oczywistego znaku prawnego władztwa, bo uważali, że prawne władztwo powstawało wobec tych rzeczy, które pochwycili od wrogów", dostęp: http://www.kamykodeks.pl/prawo/gaius -institutiones-ksiega-i-cz16.html.

${ }^{43}$ Gaius Institutiones (G. 2.24): „Natomiast odstapienie przed prawem dokonuje się w taki sposób: wobec urzędnika ludu rzymskiego, na przykład pretora miejskiego, ten, któremu odstępuje sie rzecz przed prawem, trzymajac rzecz, mówi: Hunc ego hominem ex iure quiritium meum esse aio (Ja oświadczam, że ten niewolnik jest mój wedle prawa kwirytów). Potem, skoro ten dokonal windykacji, pretor pyta tego, który odstępuje, czy dokona kontrwindykacji. Gdy ten milczy, lub zaprzecza, przyznaje rzecz temu, który windykował"; dostęp: http://www.karnykodeks.pl/prawo/ gaius-institutiones-ksiega-i-cz2.html.

${ }^{44}$ Postępowanie legisakcyjne (per legis actiones) - to najstarsza forma cywilnego postępowania sądowego w prawie rzymskim - por. W. Wołodkiewicz, M. Zabłocka, Prawo rzymskie. Instytucje, Warszawa 2009.

${ }^{45}$ K. Kolańczyk, Prawo rzymskie, s. 299-300. 
niesienia prawa własności wyszła ona z użycia w VI w., a w sposób formalny zniesiona została w kodyfikacji justyniańskiej ${ }^{46}$.

Instytucją prawną, która na długie lata ustaliła reguły przenoszenia praw do nieruchomościami, była - zdefiniowana w okresie klasycznym ${ }^{47}$ rozwoju państwa rzymskiego - metoda zwana traditio $^{48}$, która, co do zasady, jako norma wyznaczająca warunki skuteczności czynności prawnej, przetrwała praktycznie w różnych odmianach aż do XIX-wiecznych kodeksów cywilnych ${ }^{49}$, w których odnaleźć można jeszcze ustanowioną wówczas zasadę. Przyjęte w tamtym czasie rozwiązanie uzależniało skuteczność czynności przeniesienia własności od wydania przedmiotu (rzeczy) transakcji przez dotychczasowego jej posiadacza, zgodnie z ustanowioną zasadą Traditionibus et usucapionibus dominia rerum non nu dis pactis transferentur, co oznaczało, że własność rzeczy przenosi się poprzez „wręczenie i zasiedzenie”, a nie wyłącznie samą umowa $^{50}$. Skuteczne przeniesienie prawa własności na nabywcę wymagało tym samym, oprócz spisania wymaganego kontraktu (nudum pac tum), odrębnej czynności o charakterze symbolicznym, sprowadzającej się do publicznego (widocznego dla otoczenia) przekazania przez zainteresowane strony, faktycznego władztwa nad przedmiotem umowy. Skuteczność tych czynności oceniana była w kontekście ustanowionej ogólnej zasady nemo plus iris alium transferre potest, Guam ipse habet (nikt nie może przenieść na drugiego więcej prawa, aniżeli sam posiada), która chronić miała prawa właściciela przed nieuprawnionym zbyciem ${ }^{51}$.

Zdefiniowana $\mathrm{w}$ prawie klasycznym i justyniańskim procedura zbycia prawa własności składała się z dwóch etapów, z których pierwszy dotyczył czynności o charakterze zobowiązującym (,goła umowa" - kontrakt kupna-sprzedaży rzeczy), a drugi - czynności rozporządzającej polegającej na jawnym i formalnym wydaniu przedmiotu umowy. Traditio jako metoda przeniesienia własności praw do rzeczy (modus) nie wymagała tym samym obecności innych osób niż zainteresowanych stron, tj. sprzedającego posiadającego tytuł własności, zdolnego do rozporządzania swoim prawem, i kupującego, którzy zgodnie wyrazili wolę przeniesienia prawa. Natomiast jako akt „kauzalny” sprowadzała się do czynności wydania nabywcy faktycznego władania lub po-

${ }^{46}$ Kodeks Justyniana (Codex Iustinianus) to jedna z trzech części wielkiej kompilacji prawa rzymskiego podjętej w latach 528-534 przez cesarza Justyniana I Wielkiego, znanej pod średniowieczną nazwą Corpus Iuris Civilis - por. K. Kolańczyk, Prawo rzymskie, s. 37-38.

47 Datowanym od początku pryncypatu (27 p.n.e.) do objęcia władzy przez Dioklecjana (284 r. n.e.) - por. K. Kolańczyk, ibidem, s. 34-35.

48 Tradere znaczy: wydawać wręczać.

${ }^{49} \mathrm{~Np}$. austriackim kodeksie cywilnym $(\mathrm{ABG})$ z $1811 \mathrm{r}$.

${ }^{50}$ Gaius Institutiones - D.41.1.31pr (Paulus, księga 31 komentarza do Edyktu): Samo wręczenie rzeczy nie przenosi własności, lecz tylko wtedy, gdy poprzedzała je sprzedaż lub jakaś inna słuszna przyczyna, ze względu na którą nastapiło wręczenie rzeczy; dostęp: http://www.karnykodeks.pl/prawo/gaius-institutiones-ksiega-i-czl6.html.

${ }^{51}$ K. Kolańczyk, Prawo rzymskie, s. 297. 
siadania (possessio) ${ }^{52}$ rzeczy warunkującej powstanie skutków wynikających $\mathrm{z}$ istnienia i dopuszczalności przyczyny prawnej, czyli zawartego kontraktu kupna-sprzedaży zobowiazzującego do wydania rzeczy nabywcy ${ }^{53}$.

Ustanowiona reguła, warunkująca ważność czynności przeniesienia prawa do rzeczy od fizycznego jej wydania, podlegała w okresie późniejszym ${ }^{54}$ licznym modyfikacjom, zmierzającym w swej istocie do zastapienia tej czynności wymogiem zarejestrowania kontraktu stanowiącego podstawę przeniesienia prawa, wręczeniem pisemnego oświadczenia zbywcy (traditio instrumentali) czy też koniecznością publicznego ujawnienia nabytych praw, co stanowić miało swego rodzaju element kontroli społecznej, a jednocześnie materialny dowód, że prawo to przysługuje osobie w ten sposób ujawnionej.

Inną odmianą modyfikacji zasady traditio było zastapienie warunku fizycznego wydania posiadania rzeczy czynnością sprowadzającą się do przekazania nabywcy dokumentów urzędowych, potwierdzających ważność aktu przeniesienia własności, a także umożliwiających ustalenie zasięgu przedmiotowo tegoż prawa, tj. granic nabywanej własności. W średniowiecznej Anglii czy Niemczech dla skuteczności czynności przeniesienia prawa do rzeczy wobec osób trzecich wymagano publicznego jego wydania w miejscach publicznych, na przykład na rynku, w kościele czy sądzie ${ }^{55}$. Konieczność praktycznego upraszczania zasad w obrocie prawnym była zatem powodem modyfikacji pierwotnej metody traditio, zmierzającej do dematerializacji tej czynności w zakresie corpus (rzeczy), i zastapienia jej symbolicznym aktem, który czynił z niej proces przewłaszczenia własności aktem abstrakcyjnym. Należy podkreślić, że ustanowiona w prawie rzymskim dwuetapowa formuła czynności prawnej alienacji (łac. alienatio) utrzymywała się w kodyfikacjach europejskich do XIX w.

Procedurę transakcji kupna pola wraz z jego symboliką opisaną w „Księdze Jeremiasza" (32:9-14) Starego Testamentu potwierdzają z kolei znaleziska papirusów z Elefandydy, żydowskiej kolonii nad Nilem. Polegała ona na tym, że na jednej karcie zapisywano ten sam kontrakt dwa razy w taki sposób, aby możliwe było zwinięcie jednej części w rulon, który związywany był następnie sznurem i pieczętowany, podczas gdy druga część papirusu z powtórzoną treścią kontraktu była jedynie zwijana. Przyjęty sposób zawierania kontraktu miał dawać zainteresowanym z jednej strony możliwość jego swobodnego czytania, z drugiej zaś gwarancję wykluczającą możliwość ingerencji w jego treść. Rulony te przechowywane były w glinianych naczyniach, „by zachowały się przez długi czas" ${ }^{956}$.

${ }^{52} \mathrm{~W}$ okresie wulgaryzacji prawa rzymskiego (IV-V w.) termin ten służył zarówno do określenia posiadania, jak i prawa własności.

${ }_{53}$ K. Kolańczyk, Prawo rzymskie, s. 300-302.

${ }^{54} \mathrm{~W}$ czasach obowiązywania prawa justyniańskiego.

${ }^{55}$ T. Stawecki, Rejestry nieruchomości, s. 175.

${ }^{56}$ Biblia dla każdego, t. VII, red. W. Chrostowski, Kielce 2004, s. 262. 


\section{Wybrane rejestry nieruchomości w średniowiecznej Europie.} W okresie tzw. wulgaryzacji ${ }^{57}$ prawa rzymskiego (IV-V w.n.e.), w krajach germańskich czynność przeniesienia prawa własności do nieruchomości składała się z dwóch niezbędnych aktów spisywanych w obecności świadków, z których jeden zawierał złożone przez sprzedającego oświadczenie, tzw. wzdanie (resignatio), oraz oświadczenie nabywcy o objęciu przedmiotu transakcji (wwiązanie się), a drugi stanowił umowę oddania zbywanej rzeczy nabywcy (Gewere). Czynność wręczenia dokumentów przeniesienia własności w obecności świadków (traditio per cartam) stanowiła tym samym wystarczający warunek jej prawnej skuteczności. Podobnie było jeszcze w czasach justyniańskich, w których praktykowano powszechnie zasadę publicznego wręczenia kupującemu jedynie samego oświadczenia zbywcy (traditio instrimenti), które jako takie sprowadzało się do postaci symbolicznego wydania „substytutu" przedmiotu umowy, czyniąc tym samym akt przeniesienia prawa własności „fikcyjnym” (traditio ficta) ${ }^{58}$, bo pozbawionym elementu fizycznego wydania nabywcy rzeczy.

W średniowiecznym ustawodawstwie frankońskim (IX w.) wprowadzono zasadę, że dowodem przeniesienia własności rzeczy, oprócz aktów o charakterze traditio cartae moga być dokumenty (zaświadczenia) zwane notitia (memoratorium), potwierdzające fakt, że dana czynność została skutecznie dokonana.

W okresie późniejszym w niektórych miastach niemieckich umowy przeniesienia prawa własności do nieruchomości spisywane przed sądem lub radą miejską zaczęto ujawniać w specjalnych księgach, dla których z biegiem czasu przyjęto zasadę mocy dowodowej ujawnionego w nich wpisu, który stał się jednocześnie warunkiem skuteczności dokonanych czynności w tym zakresie. Przyjęty wówczas system rejestrowania czynności zbywania praw do nieruchomości stał się pierwowzorem późniejszych ksiąg gruntowych (ksiag wieczystych). Warto także podkreślić, że tak prowadzone rejestry mogły być „udostępniane każdemu, kto sprawdzał lub podważał zawarcie umowy"59. Przyjęta wówczas zasada sprawiła, że czynności zbycia dokonane bez udziału sądu nie były skuteczne. Sąd stał się tym samym gwarantem zawartego kontraktu, a także instytucją odpowiedzialną za wydawanie orzeczeń w sprawach niespornych ${ }^{60}$.

${ }^{57}$ To okres rozwoju prawa datowany od Konstantyna Wielkiego do Justyniana (od słowa: vulgaris - ludowy, pospolity). Termin ten wiąże m.in. się z upadkiem cesarstwa zachodniorzymskiego w 476 r. i okresem, w którym prawo rzymskie przejmowane przez napływające ludy barbarzyńskie wchodzące w skład imperium było upraszczane i zniekształcane - por. K. Kolańczyk, Prawo rzymskie, s. 77-80.

58 Ibidem, s. 302.

${ }^{59}$ H.J. Berman, Prawo i rewolucja. Ksztaltowanie się zachodniej tradycji prawnej, Warszawa 1995, s. 438.

60 T. Stawecki, Rejestry nieruchomości, s. 177. 
W średniowiecznej Europie, w okresie feudalizmu, czynności zbycia praw do posiadania nieruchomości odbywały się obowiązkowo w obecności seniora, którego pozycja społeczna gwarantować miała ważność przeniesienia praw lennych ${ }^{61}$ przez wasala na innego wasala. Ceremonia przekazania lenna, zwana inwestytura, w swej istocie polegała na tym, że zainteresowany (wasal) nabywał prawa do władztwa nad nieruchomością od seniora, a nie bezpośrednio od innego wasala (poprzedniego dzierżyciela). Charakter inwestytury czynił z niej przy tym instytucję porównywalną do traditio ficta $\mathrm{w}$ zakresie publicznego ujawnienia czynności przeniesienia władztwa nad nieruchomością. W przypadkach zaś, w których przeniesienie posiadania odbywało się bez udziału seniora, ważność i skuteczność tej czynności uzależniona była od publicznego jej ujawnienia, czego przykładem była instytucja niemieckiej $\mathrm{Ge}$ wery. W początkowym okresie publiczne ujawnienie przeniesienia władztwa nad nieruchomością ograniczało się do ustnego oświadczenia złożonego przez dotychczasowego posiadacza we wskazanym zwyczajowo miejscu. W okresie późniejszym zwyczaj ten zastapiony został formalnym obowiązkiem ujawnienia przez dotychczasowego posiadacza czynności zbycia posiadanego prawa w odpowiedniej księdze ${ }^{62}$.

W średniowiecznej Anglii pierwsze urzędowe rejestry nieruchomości, zwane „Księgami strasznego sądu” (The Domesday Book), były zakładane na podstawie wyników powszechnego spisu feudalnego, przeprowadzonego w latach 1085-1086. Wyznaczeni przez Wilhelma Zdobywcę sędziowie zapisywali w nich dane pozwalające ustalić, komu monarcha przyznał prawo do posiadania określonego majątku ziemskiego, a także wysokość należnego władcy lenna, które na tej podstawie podlegało egzekucji ${ }^{63}$. Przyjęty system ksiag umożliwiał także ujawnianie w nich instytucji przeniesienia (przewłaszczenia) prawa posiadania w zamian za zabezpieczenie długu na nieruchomości, która - jako rozwiązanie systemowe - mogła stanowić pierwowzór dzisiejszej hipoteki gruntowej (mortgage) ${ }^{64}$.

$\mathrm{Z}$ uwagi jednak, że tak prowadzony rejestr nie był na bieżąco aktualizowany, do przeniesienia prawa władania ${ }^{65}$ nieruchomości stosowane były w praktyce rozwiazania (libery of sesin) wzorowane na instytucji rzymskiego traditio

${ }^{61}$ Prawo lenne to średniowieczne prawo zwyczajowe, kształtujące stosunki pomiędzy seniorem a wasalem.

62 P. Dąbkowski, Prawo zastawu w Zwierciadłach Saskiem, Szwabskiem, Niemieckiem, Studyum $z$ historyi prawa niemieckiego, Lwów 1913, s. 70, w: T. Stawecki, Rejestry nieruchomości, s. 175.

${ }^{63}$ K. Krasowski, B. Lesiński, K. Sikorska-Dziegielewska, J. Walachowicz, Powszechna historia, s. 71; por. T. Stawecki, Rejestry nieruchomości, s. 181.

${ }^{64}$ T. Stawecki, M. Tomaszewski, F. Zelder, Ustawa o zastawie rejestrowym i rejestrze zastawów. Komentarz, Warszawa 1997, s. 178, 183-187, 211-213, 222.

${ }^{65} \mathrm{~W}$ okresie feudalnym w Anglii nie rozróżniano, tak jak w prawie rzymskim, pojęcia własności (dominium) i posiadania (possessio) nieruchomości. System ten opierał się na pojęciu dzierżenia nieruchomości przez wasala. Brak było własności alodialnej, tzn. wolnej od ciężarów i zobowiązań feudalnych (lenna). 
lub germańskiego Gewere, w których element faktycznego wydania rzeczy, mający często charakter ceremonialnego przekazania nabywcy symbolu związanego $\mathrm{z}$ nieruchomością (np. w postaci grudy ziemi, gałązki z drzewa, krzyża itp.), stanowił o skuteczności dokonanej czynności. Z czynności wydania rzeczy nabywcy spisywany był czasem po łacinie akt (deed), który dokumentować miał przebieg tej ceremonii i zaświadczać jednocześnie, że się ona odbyła, a także - w miarę moźliwości - precyzować granice zbywanej nieruchomości. Ukształtowane w okresie feudalizmu pojęcie sesin, które w swej pierwotnej postaci bliższe było znaczeniowo instytucji posiadania (possessio) niż własności (dominium), ulegało z czasem zmianom, które w XIII w. doprowadziły do wyodrębnienia $\mathrm{z}$ niej, jako niezależnej od innych, formę władania nieruchomościa przez czas nieograniczony (freehold estate), przekształcając się w okresie późniejszym we własność definiowana, jako comman law, i szereg słabszych form władania (non-freehold) ${ }^{66}$.

Potrzeba ochrony interesów osób władających nieruchomościami przed nieuprawnionym ich usunięciem sprawiła, że zaczęto rejestrować prawa wynikające z zawartych kontraktów w rejestrach sądowych, co przyczyniło się między innymi do powstania instytucji dzierżenia na podstawie wpisu do akt sądowych (copyhold), a w okresie późniejszym (od XV w.) do tworzenia systemów rejestrowania aktów przeniesienia własności.

Z inicjatywy Henryka VIII parlament Anglii przyjął w 1535 r. ustawy The Statue of Use i The Statue of Enroments, w których dla uporządkowania istniejącego stanu faktycznego, wynikającego z praktyki nieformalnego przenoszenia prawa użytkowania nieruchomości (ces tui que use), dającego jego posiadaczowi tytuł do używania i pobierania pożytków (beneficial interest property), zastosowano rozwiązanie, w ramach którego nadano tym użytkownikom prawo własności legalnej (legal owner), a także - w celu zapobieżenia w przyszłości wystapieniu podobnych przypadków - wprowadzono zasadę obligatoryjnego rejestrowania aktu przeniesienia własności nieruchomości (ded) w cort of rekord w Westminsterze lub innym publicznym urzędzie wyznaczonym do tego celu, w ustalonym terminie sześciu miesięcy, po którego przekroczeniu - w razie niezarejestrowania - kontrakt taki stawał się nieskuteczny ${ }^{67}$.

Przyjęty model przenoszenia praw do nieruchomości utrzymywał się z pewnymi modyfikacjami - aż do czasu likwidacji własności feudalnej (koniec XVII w. ${ }^{68}$. W tym okresie dokonywane zmiany związane były z wywłaszczeniem dotychczasowych dzierżycieli w związku z przeprowadzaną reformą konsolidacji własności ziemskich (ogradzaniem posiadłości). Wykształciły się wówczas nowe formy powiernictwa ziemskiego (trust), a przede wszystkim

${ }^{66} \mathrm{~S}$. Rudnicki, Systemy ksiag wieczystych i zabezpieczeń majatkowych na nieruchomości w większości krajów europejskich, „Rejent” 1995, nr 11, s. 28.

Ibidem, s. 27, 55. -1690 .

${ }^{68}$ To okres kolejnych rewolucji angielskich, jakie miały miejsce w latach 1640-1660, 1688- 
instytucja przewłaszczenia jako skuteczna metoda zabezpieczenia wierzytelności na nieruchomości ${ }^{69}$. Przeprowadzane zmiany ustrojowe wzmacniały jednocześnie samo pojęcie prawa własności, które w odbiorze powszechnym zaczęto traktować jako absolutne i nienaruszalne (święte), osłabiając tym samym w praktyce formalne wymogi związane $\mathrm{z}$ obowiązkiem rejestracji aktów zbycia, co przyczyniło się wydatnie do podważenia wiarygodności instytucji publicznych (sądów), w których gromadzono dokumentację dotyczącą nieruchomości ziemskich.

W średniowiecznej Europie wpływy prawa rzymskiego na kształtowanie zasad regulujących procedurę przeniesienia praw do nieruchomości były widoczne również na przykładzie południowych ziem Francji, na których instytucja traditio przetrwała praktycznie aż do czasów Kodeksu Napoleona (1804). Natomiast prowincje północne Francji pozostawały pod wpływem germańskiego prawa zwyczajowego (tzw. pays de coutumes) ${ }^{70}$, które w okresie późniejszym zastępowane było klauzulami umownymi, przekształconymi $\mathrm{z}$ czasem $\mathrm{w}$ formalny obowiązek sądowej rejestracji ${ }^{71}$ czynności rozporządzających nieruchomościami i publicznego ich ujawnienia ${ }^{72}$. W Bretanii ogłoszenie o przeprowadzonej transakcji podawane było przez nabywcę nieruchomości trzykrotnie w niedzielę, co siedem lub czternaście dni. Jeżeli w tym okresie nikt nie zgłosił zastrzeżeń do treści umowy, prawa nabywcy lub wierzyciela podlegały ochronie. Już w czasach nowożytnych w niektórych prowincjach południowej Francji wprowadzony został system, wywodzący się jeszcze $\mathrm{z}$ czasów inwentury, który nakładał obowiązek ujawniania $\mathrm{w}$ rejestrach prowadzonych przy sądach zmian wynikających z czynności przeniesienia praw do nieruchomości, ustalał $\mathrm{w}$ zawieranym kontrakcie zwierzchnią pozycję zbywcy (seniora), a także wprowadzał - jako zasadę - ochronę praw nabywcy, który pierwszy dokonał rejestracji zawartego kontraktu, co służyć miało legalizacji przeprowadzanych czynności. Na terytorium całej Francji, system ten - w zmodyfikowanej formie - został wprowadzony około stu lat później, w czasie rewolucji francuskiej.

W średniowiecznej Polsce skuteczne nabycie praw do posiadania nieruchomości wymagało odrębnego aktu, stanowiącego dowód wejścia nabywcy $\mathrm{w}$ ich władanie ${ }^{73}$. $\mathrm{Z}$ tego też powodu wydanie nabywcy gruntów łączyło się zarówno z koniecznością wytyczenia ich granic poprzez obejście lub objazd

${ }^{69} \mathrm{~K}$. Michałowska, Trust $\mathrm{i}$ stosunki powiernicze w prawie angielskim, ,Kwartalnik Prawa Prywatnego" 1996, z. 2, s. 297-298; A. Kędzierska-Cieślak, Powiernictwo. Próba określenia konstrukcji prawnej, „Państwo i Prawo” 1997, nr 8-9, s. 48-49.

${ }^{70}$ K. Koranyi, Powszechna historia, s.195.

71 Sądowa rejestracja zwana była nantissement.

72 Te dwa różne systemy obowiazywały we Francji od IX do XIII w. - por. K. Koranyi, K. Sójka-Zielińska (oprac.), Powszechna historia prawa, Warszawa 1976, s. 195.

73 Element wydania rzeczy przy jej sprzedaży, jako warunek skuteczności dokonanej czynności przeniesienia własności wynikał z obowiązującej w wielu krajach europejskich rzymskiej zasady traditio. 
konny, jak i z obowiązkiem sporządzenia szczegółowego pisemnego ich opisu, „który w razie potrzeby mógł służyć za dowód w sporze ${ }^{\Re 74}$. W przypadku posiadłości o mniejszej wartości akt ten ograniczał się czasem do publicznego (w obecności świadków) złożenia pod przysięgą oświadczenia zbywcy o przeniesieniu praw do nieruchomości i dokonania czynności o charakterze symbolicznym, który oznaczać miał wydanie zbywanej rzeczy, na przykład poprzez włożenie nabywcy czapki na głowę, wręczenie rękawiczki lub zielonej gałązki. Umowy dotyczące przeniesienia praw własności ziemskiej zawierane były na piśmie już około roku $1000^{75}$.

Wraz z rozwojem na terenach polskich rejestrów urzędowych prowadzonych w sądach, ale także na dworach książęcych, znaczenie tak sporządzonych dokumentów jednak malało. Większą wagę zaczęły mieć dokumenty wydawane bezpośrednio przez kancelarie rejestrowe książąt (np. Metryka Koronna lub Metryka Mazowiecka) lub udostępniane z rejestru zapadłych orzeczeń lub czynności dokonanych bezpośrednio przed sądem ${ }^{76}$.

W prowadzonych wówczas ,regestrach sądowych" (tabulae iudicii) ${ }^{77}$ były odnotowywane wzmianki o dokonanych przed sądem aktach sprzedaży gruntów, tzw. wzdaniach (resignatio), które, traktowane jako oświadczenia dotychczasowych właścicieli o wyzbyciu się posiadanego prawa na rzecz wskazanego nabywcy, miały zastapić tzw. instytucję wsteczy, polegającą na uzgadnianiu z sędziami faktu wcześniejszego złożenia przed nimi oświadczeń, dotyczących wyzbycia się praw do wskazanej rzeczy ${ }^{78}$. W rejestrach tych, co ciekawe, odnotowywano również wyroki sądów rozstrzygające spory graniczne czy ustanowione na nieruchomości prawa rzeczowe o charakterze zabezpieczającym, na przykład w zakresie zastawu. Tak prowadzone księgi grodzkie nabyły z czasem prawo do zamieszczania w nich tzw. wpisów o charakterze wieczystym ${ }^{79}$. Nie wymagały bowiem one - do uzyskania mocy dowodowej ujawnionego w nich wpisu - jego potwierdzenia na podstawie dokumentu wydanego z innego rejestru, na przykład ziemskiego. Podkreślić należy jednak, że brak ujawnionego wpisu w księgach grodzkich potwierdzającego posiadanie praw do określonej nieruchomości nie stanowił formalnej przeszkody uniemożliwiającej skuteczne przeniesienie prawa własności. W takich przypadkach zbywca musiał obowiązkowo potwierdzić swoje uprawnienia do sprzedawanej nieruchomości w obecności świadków ${ }^{80}$.

\footnotetext{
74 J. Bardach, Historia państwa i prawa Polski, Warszawa 1964, s. 299.

${ }^{75}$ Ibidem, s. 229; por. J.W. Bandtke-Stężyński, Historya prawa polskiego, Warszawa 1850, s. 224.

${ }^{76}$ T. Stawecki, Rejestry nieruchomości, s. 178.

${ }^{77}$ W Polsce pierwsze wzmianki o nich pochodzą z 1322 r. - por. T. Stawecki, Rejestry nieruchomości, s. 373-374.

${ }^{78}$ A. Menes, Wiadomości wstępne dotyczace ksiag wieczystych, „Rejent” 1994, nr 4, s. 58.

79 Takie uprawnienia nabyły w XV w. ksiegi prowadzone przez grody wielkopolskie.

${ }^{80}$ T. Stawecki, Rejestry nieruchomości, s. 179.
} 
Intensywny rozwój rejestrów nieruchomości (ksiag wieczystych) datowany jest $\mathrm{z}$ chwilą rozpowszechnienia wymiany handlowej, opartej na sile nabywczej pieniądza, rozwojem instytucji kredytu realnego i koniecznościąjego majątkowego zabezpieczenia w formie hipoteki ${ }^{81}$. Instytucja hipoteki, której początki sięgają starożytnej Grecji, postrzegana jako szczególny rodzaj zastawu umownego (zastaw bez dzierżenia) ${ }^{82}$, w ramach której obciaż̇ona umową nieruchomość pozostawała w rękach dłużnika, przyczyniła się do rozwoju rejestrów gruntowych w całej średniowiecznej Europie. Zapisanie prawa własności do nieruchomości w urzędowym rejestrze służyć miało nadaniu aktowi prawnemu alienacji cech trwałości (wieczystej) i dawać właścicielowi gwarancję ochrony prawnej ujawnionych praw, a wierzycielom pewność zabezpieczenia ich interesów.

Średniowieczne rejestry nieruchomości, wśród których wymienić można polskie księgi ziemskie i grodzkie, niemieckie księgi miejskie i gruntowe, w północnej Francji rejestry sądowe, czy też angielskie księgi sądowe postrzegane sa jako instytucje prawa. Za pomoca tych instytucji państwa, na obszarze których zostały one założone, kontrolowały czynności cywilnoprawne dotyczące przenoszenia praw do nieruchomości oraz gwarantowały jawność formalną stosunków prawnorzeczowych, dotyczących nieruchomości. Prowadzone księgi koncentrowały się przede wszystkim na rejestrowaniu i identyfikowaniu osób, którym przysługiwały określone prawa rzeczowe oraz wykazywaniu obciążeń na nich ustanowionych, w mniejszym zaś stopniu zwracając uwagę na opis samego przedmiotu tych praw (działek gruntowych).

Przedstawione $\mathrm{w}$ artykule rozważania dotyczące rejestrów nieruchomości (ksiąg gruntowych, ksiąg hipotecznych) w ujęciu diachronicznym, funkcjonalnym i porównawczym prowadzić miały do zidentyfikowania typowych cech i funkcji, jakie pełniły one na przestrzeni wieków w systemach prawnych różnych krajów, a także do uwypuklenia istotnych odmienności, pozwalajacych między nimi na dostrzeżenie ratio legis utworzenia tych instytucji prawa, a także powodów ich modyfikacji.

${ }^{81}$ J. Wasilkowski, Prawo rzeczowe w zarysie, Warszawa 1957, s. 316; por. O. Balzer, Hipoteka w dawnym ustawodawstwie polskim, „Gazeta Sądowa Warszawska” 1888, $\mathrm{nr}$ 29, s. 475.

82 K. Sójka-Zielińska, Historia prawa, Warszawa 2005, s. 148. 